MASS TRANSFER IN A SALT REPOSITORY*

Thomas H. Pigford and Paul L. Chambre'

அレU \&

Earth Sciences Division, Lawrence Berkeley Laboratory

and

Department of Nuclear Engineering, University of California

Berkeley, California 94720

May, 1985

DISCLAIMER

This report was prepared as an acoount of work sponsored by an agency of the Unitod States Government. Neither the Unined States Covernment nor any ayency thereof, nor any of their employees, makes any warrasty, express or impliod, or asumes any legal liability or responsibility for the nocuracy, completeaces, or uefulaess of any informalion, apparatus, product, or proces disclowed, or represeats that its we would eot infriese privately owned rights. Reference herein to any perific ounerecial product, proceece, or service by trade anac, trademart,

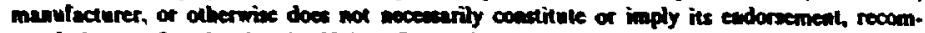
meadation, or farorien by the Unived Stales Gowereinest of any secacy thereof. The view

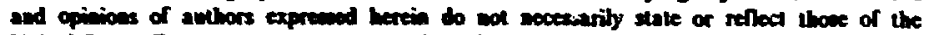

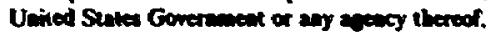

Frepared for the U.S. Depactent of Energy uader contract nubber nos-1003-765F00098 by the Anetetant Secretary for Muclear Englaceriag. Offlce of Civilian Nuclear Waste Nanageneat, Divieion of Nuclear vaste Inollation. 


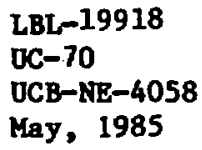

\section{MASS TRANSFER IN A SALT REPOSITORY}

Thonas H. Plgford and Paul L. Chambre"

Department of Nuclear Englneering and Lawrence Berkeley Laboratory University of California

Berkeley, Californfa 94720

\section{Abstract}

To meet regulatory requirements for radioactive waste in a salt repositor? It is necessary to predict the rates of corrosicn of the waste container, the relesese rates of radionuclides fron the wate package, and the cunulative release of radionuclides into the accessible environment. The mechandens that nay control these rates and an approach to predicting these rates fron masstransfer theory are described. This new mechanlstic approach is suggested by three prentees: (a) a brine inclusion originally in a salt crystal woves along gratn boundartes after thernal-induced algration out of the cryetal, (b) brine moves along a graln boundery under the influence of a pressure gradient, and (c) salt surrounding a heat-generating waste package will coon creep and consolidate at wonolithic mediun surrounding and in contact whth the waste package. After consolidation there nay be very little algration of intergranular and intragranular brine to the waste package. The corrosion rate of the waste contalner ay then be lindted by the rate at which brine reeches the contalner and any be celculable from mass-tranefer theory, and the rate at which diacolved radionucliden leave the wate package any be ilnited by molecular diffusion in intragramular brine and any be calculable fron mastransfer thoory. If porous monalt Interbods j.atersect the vaste-package borehole. the release rate of discolved radionuclides to laterbed brine may al wo be calculable from ano-tranefer theory. The loske of these conclustone 1. described, se an atd in formulating the calculations that are to be ande.

1. Wotion of uriae in Bated Folveryatalline Salc

Dadloactive decuy of high-level redloact iw wate aplaced in natural

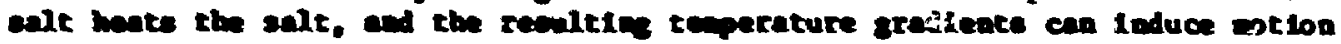

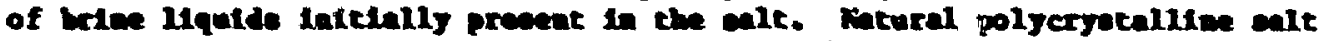

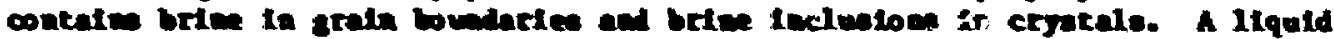

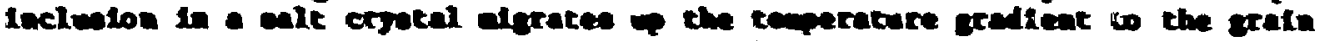

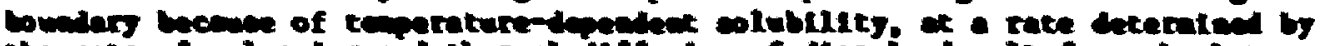

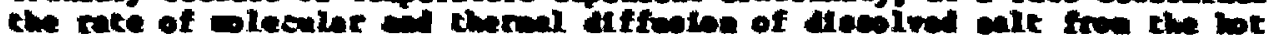

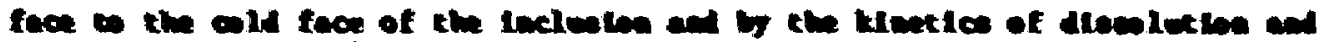

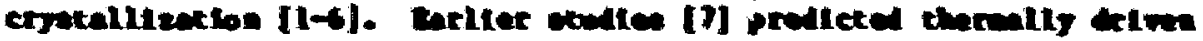


transport of brine towards the waste package, assuning that a brine inclusion In a cryetal wes across the grain boundary into the adjacent crystal and finally reaches the waste package.

Later experlments [8] Indicated that brine reaching a grsin boundary remalns within the graln boundary rather than moving into ad facent crystals, and subsequent analyses [9-11] assumed that the grain-boundary brine woves along the grain boundary at a velocity proportional to the pressure gradient. Although the law of pressure-1nduced notion of grain-boundary brine is not known $_{y}$ it is assumed here that the motion of grain-boundary brine increases wth pressure gradient and depends only on the pressure gradient. Because the pressure gradient is not necessarily in the same direction as the tenperature gradient, as lllustrated below, It 18 not necessary that brine wove towards the waste package.

2. Flow Into a Low-Presaure Cavity Surrounding the Waste Package

To explain the pressure-induced motion of grain-boundary brine, assume for simplicity that all inclusion brine has reached the grain boundarles, that brine transports along grain boundaries as through interconnected pores, and that the salt and pore ilquid behave as a thermoliatlc mediun. Pressure gradiente to cause the traneport of intergranular brine can be developed by the existance of a low-pressure boundary, as would occur if a cavity exists between the wate package and salt and by a temperature gradient within the salt. Brine in reglons of higher temperature will be at a higher pressure than the liquid In cooler alt, because the liquid brine has a higher cefficlent of thermal expancion than does the surrounding salt.

If the waste package is whin a cavity such that the annular space between the waste contatner and alt is at near-atmospheric pressure, sone of the Intragranular brine wll flow into the waste cavity and other intergranular brine will flow outward into coler alt. Figure 1 lllustrates the pressure profile that wil reault with m intragranular flow and the profiles that will result after preseure-1nduced flow, ssewing a low-preseure cavity ourrounding the wate packne and aceuting ateady temperature profile. In Figure 1 and In subeequent illustration it is escuned that salt creep resulta in a etationary flutd preasure of intergranular brine that is near or equal so the Ilthoetatic presenre, rather than the hydroatatic preseire of pore liquid that would occur if the rock behnea as anjielding porcus akeleton.

Do Inte a boulies calculation of the mation rate of releate of radionaclice fron the wate peckne, the salc Repository Project, which is

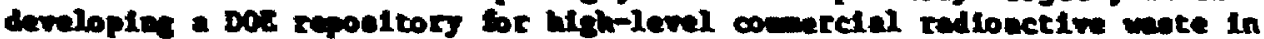

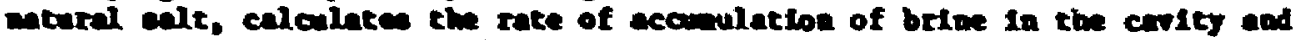

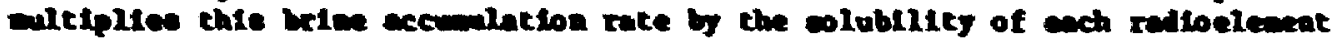

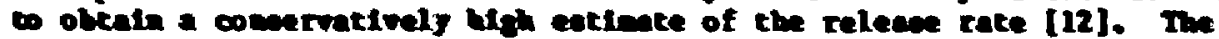

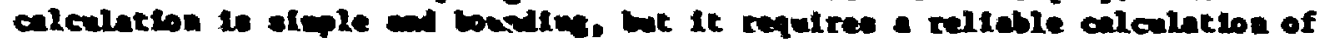

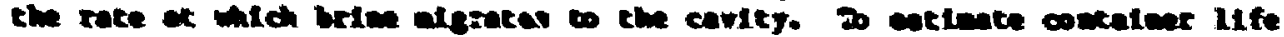

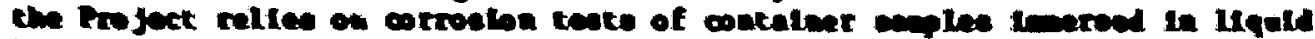

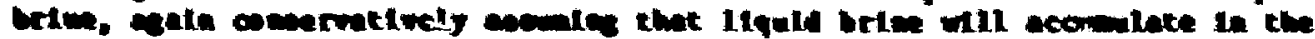




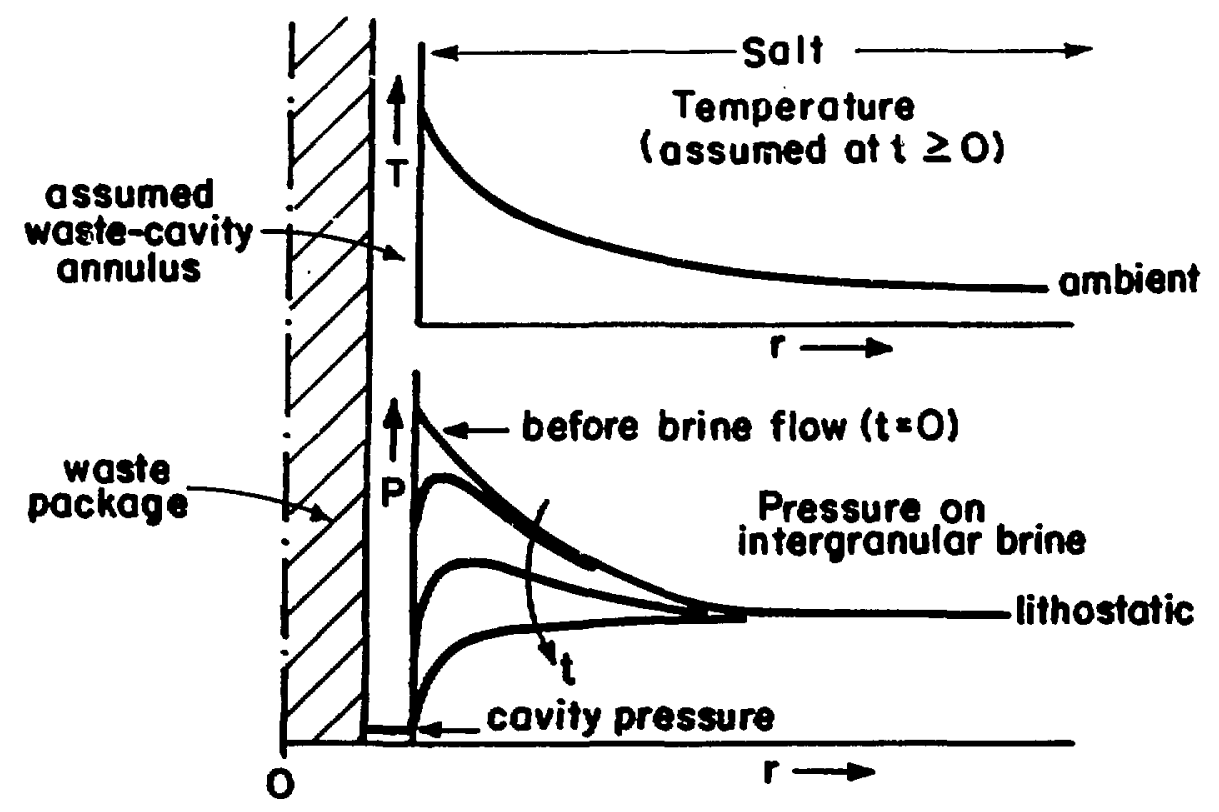

Figure 1. Profiles of pressure on intergranular brine neglecting salt creep (ateady cemerature profile assuned for illustraction) 
waste cavity. Here the cheatcal composition of the accumulated brine 18 the principal brine property affecting corrosion rate.

A wre realistic calculation by Ratigan [13] considers the ef fect of salt creep and suggests that the cavity surrounding the waste package will not exiat during the tise period of interest. If 80 , the boundary condition affecting brine migration 1s considerably changed, and there may be a simpler method of estimating rates of radionuclide release and container corrosion. This idea 18 developed In the following section.

\section{The Effect of $\underline{\text { Salt }}$ Creep}

In a salt repository for high-level radioactive waste the maximum salt temperature occurs whth a decade after waste emplacement and slowly relaxes for the next few hundred years. The waste contalner is required to withstand corrosion by inconing brine for 300 years or longer [14], and release of radionuclides from the waste package into surrounding brine or salt nust be predicted to at lesst 10,000 years. On this time scale creep of salt 18 apprectable, even at ambient temperature.

Ratigan [13] predicts that alt surrounding a waste package will creep and consolidate as anolithlc structure surrounding the waste package whthin a few years after emplacement. Here concolidation refers to the filling of volds and gaps by alt creep. For any natural salt the actual coneolidation the will depend on the rate of heat generation, the amount of salt backftll (If any), difensions of the eplacenent hole and waste container, repository depth, and creep properties of the salt. For such early consolidation we should analyze brlue transport without assuning a low-pressure cavity for brine to flow lato.

If brine were continuously driven towards the wase package by theranly induced force, as assuned in earlier analyses of brine aigration [7], the lack of aw-presure cavity need not affect the brine inflow. Brine thermally driven to the wate packate could displace the eurrounding ealt and crente tte owa cavity, if not firat conouned by cheatcal reaction with the contalner. Howerer. of flow depende on the boundary condition at the container-ealt interface. The ealt tende to consolidate to that the interface preasure rises to the lithosatic preseure. If the ealt is heted wre ropldly than it can relleve thereal etreas by creep. the ealt adjecent we the contalner will be under additional compreanion benuse of thernal expansion of the hot calt. Fluid wthin the graid boudacies expande wre wea heated than does the ealt, 0 betins senerates a presture on confloed fluld that to greater than the lithotecle prescure. Therefore, seilectios the effect of brine-container cheiced renction. the fluid preasere at the interface of the contateer and

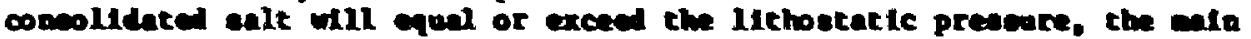
drifies force tor cresp and comolidation.

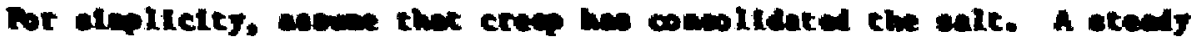

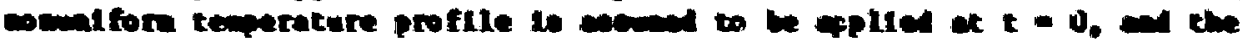


effect of chemical reaction between brine and the container is neglected. Heating puts the hot salt under further conpression, increasing the contact pressure between waste package and salt. The resulting profiles of fluld pressure before and after flow and creep are shown in Figure 2. Salt creep and outward wotion of the brine provide fluid expanston and reduce the fluid motion to zero. The brine flows outward into the cooler salt until a zero gradient of fluld pressure ts reached. Surface tension can result in a brine film between the salt and waste package. The local fluid pressure of this liquid filn can temporarily exceed the local compressive stress on the salt until outward flow of brine through grain-boundary pores relaxes the fluid pressure to 1ithostatic. Thereafter there is no mechanism for brine to flow across the package-salt interface, other than consumption of brine components by chemical reaction or radiolysis.

The sequence of heating, salt creep, and brine flow, after consolidation of salt around the waste package, need not be the simplified sequence assumed here for tllustration. Gradients tn flutd pressure caused by heating and cooling are relleved by fluid displacement and by creep, relaxing the fluid pressure to the constant lithostatic pressure.

These local adjustments in stress, strain, and density of the hot salt and intergranular brine near the waste package are likely to follow the temperature changes without signiflcant time delay. However, thts should be verified by calculation. Later, when the salt near the waste package begins to cool, some brine must move from the outer salt into the inner cooling salt where the brine density is now increasing, but no net brine transport at the package-salt interface is expected, other than that required by chemical and radiolysis reactions.

4. Effect of Chenical Reaction of Brine with the Contalner

Now the Imaginary salt-like waste package considered above is replaced with a real waste package whose container can react with brine. The wolld producte of the brine-aetal reaction are of lower denstty than the orfginal netal. 0 the salt-contalner reaction must generate a higher pressure against the surcounding salt and wut cause outward elastlc and plastc strain. This recults in a locally higher fluld pressure that oves fluld outward, away from the waste package. Bowever, brine can atill reach the container surface. though it any be inpeded by the ass-transfer realatance of the corrosion product on the surface as well as by the diffustonal realstance in the gralnboundary pores.

Water in bribe reacts with a ferricle cuncalner to generate hydrogen. The hydcosen wust ove outwand froe the eurface, through the intergranular pasaces that contain brine, w alxture of brine and hydrogen nust oxist

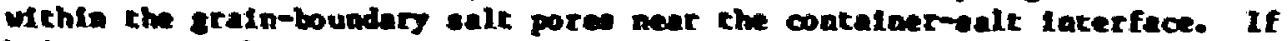
bydrogea diseolves in the brine, the coscentration of miter in the Ifquid mear

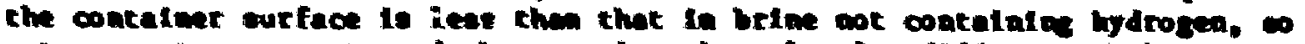

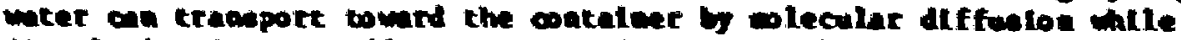

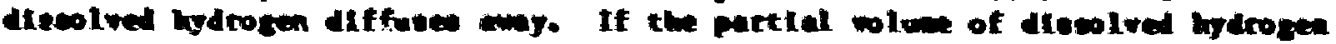




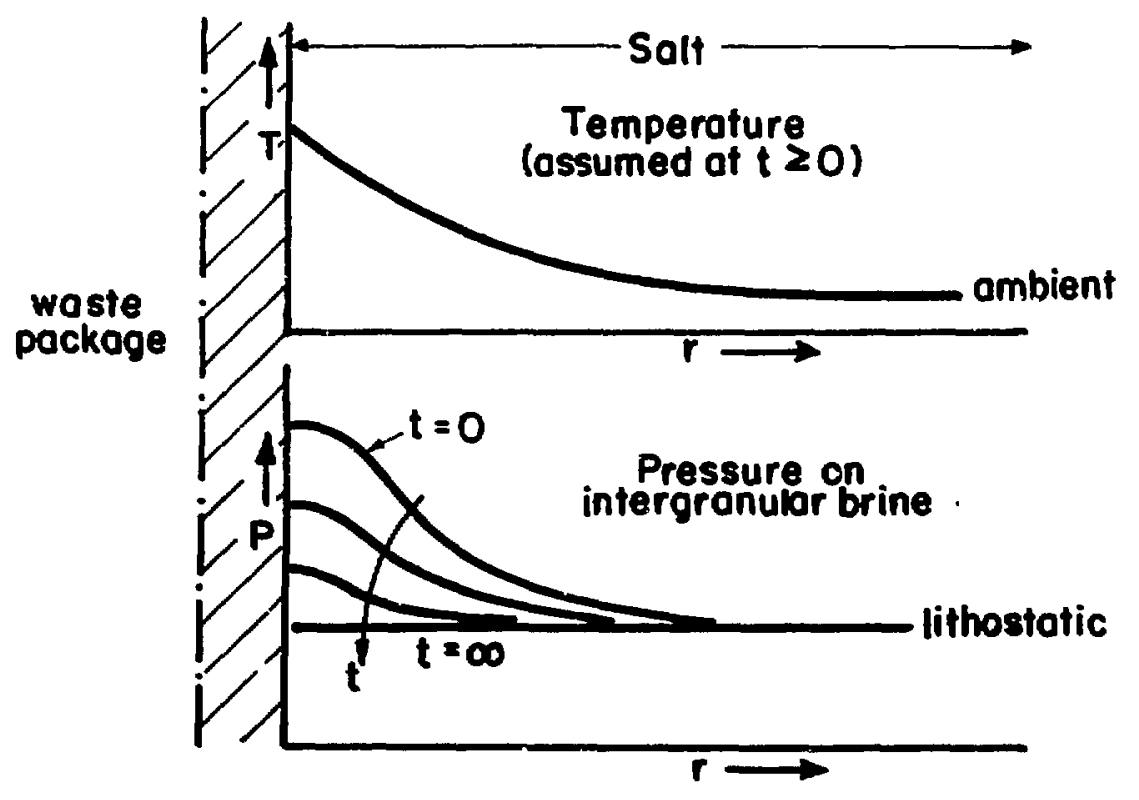

Figure 2. Profiles of pressure on intergranular brine if creep has consolidated salt againat the waste package (for 1llustration, we assure that creep has initially consolidated the salt and a steady temperature profile is then Inposed at $t=0$ ) 
Is less than that of the reacted water, and if not offset by the wolune expansion of the solid corrosion products, the container-water reaction can also result in a slight positive pressure gradient that may contribute to sone Inward flow of brine, as illustrated in Figure 3.

Conservatively assuning an infinite reaction rate of container with water and neglecting the diffustonal resistance of the solid reaction products, we can calculate from mass-transfer theory a untfora-corrosion 11 fe of the container. Because molecular diffusion through the intergranular passages is likely to be very slow, this calculated corrosion life can be less than that: extrapolated from laboratory corrosion experiments, where a metallic sample is immersed in excess liquid.

Sweden's KBS project [15-17] ut1lizes a simflar approach towards predicting the corrosion 11 fe of a thick copper contalner, limited by the calculable rate of diffusion of sulfide in groundwater through bentonite backf111. Several Independent reviews have found the KBS approach to be acceptable.

5. Estimating Radionuclide Release Rate

A simple and bounding estimate of the rate of radionuclide release from the waste package into surrounding consolidated salt can be made by assuming that the contalner is not there, assuming saturation concentrations of radioelenents in grain-boundary brine adjacent to the waste surface, and calculating the rate of colecular diffuston of the dissolved radioelenents and thelr 1sotopes through the grain-boundary brine. Although there may be sone finite influx of brine into the waste-package interstices when the contalner fails, we can conservatively assume that the interstices are traediately filled with brine and that the reaction of brine with the waste form quickly brings all of this liquid to saturation concentration. Further flow of liquid into the interatices is unlikely because the solid reaction products are of lower denatty aidd because of the expected (and required) very low rate of discolution of the waste aterial. If the presaure-Induced trine flow is very sall, brine receseary to contique the sall but finite dissolution reactione

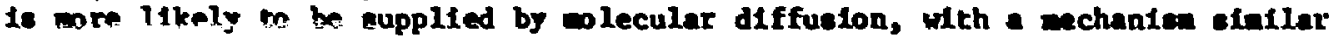
to but slower then that described above for contalner corroston. Therefore, the problea of releace rate from the vaste package can be reduced conservatively to that of calculating the rate of olecular diffusion of discolved spectes through gratn-boundery brine, beginning at the packuge/salt Interface and extending into the ealt.

This is the ene ane-tranafer andyels $[18,19]$ that hes been presented for the decolution of radioelenente from a mate package inediately

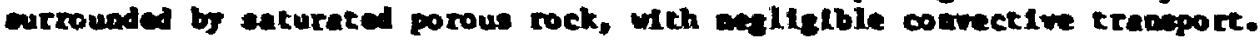

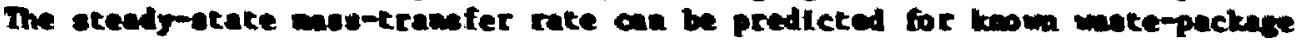

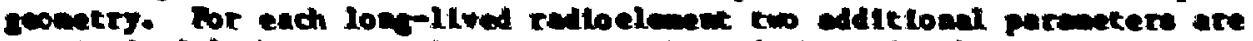

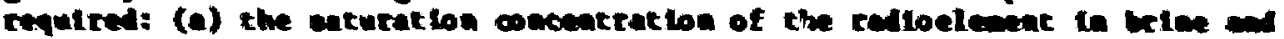

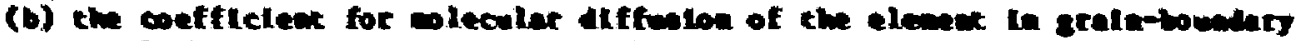

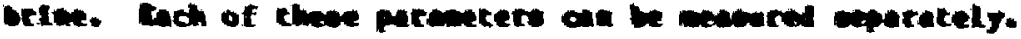




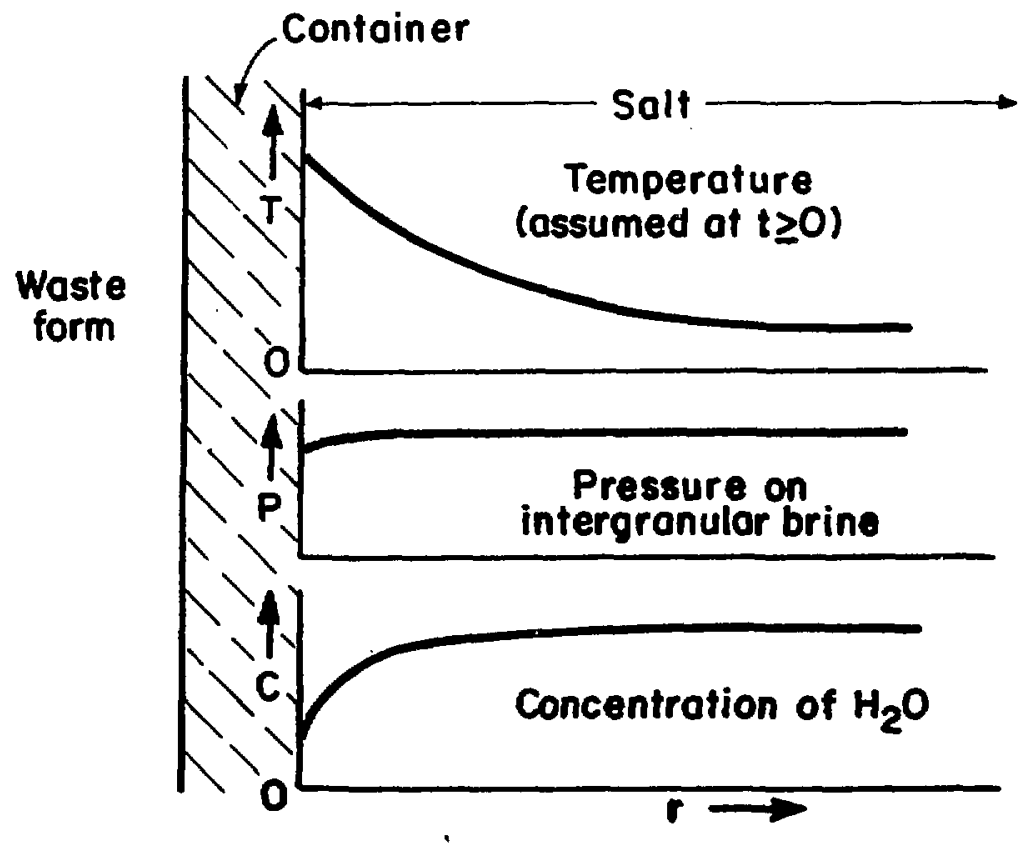

Figure 3. Profiles of fluid pressure and water concentration, with container-water reaction (steady temperature profile assumed for 11 lustration). 
The tiwe to reach steady state mass transfer is likely to be very long, 80 the transient rate of mass transfer into the salt must also be considered, requiring as an additional parameter the retardation coefficient of the radioelement due to sorption on the salt [19].

\section{Summary of Brine Transport in Salt}

If there is early consolidation of salt around the waste package, it seems itkely that brine transport may never be appreciable or will have long since ceased over wost of the several-hundred-year period of contalner life and by the time radioelement release can be important. The resulting release-rate estimates from mass-transfer analysis seem likely to be more reallstic and smaller than those calculated from the estimated rate of brine accumulation in a hypothesized waste cavity. They do not require knowledge of the rate of brine transport along grain boundaries. They rely on the mass-transfer theory that has already been extensively studied.

The foregoing discussion of expected mechanistas of consolidation and brine migration suggest different kinds of experiments and analyses than have been carried out hereto fore to characterize brine migration in a salt repository. In fact, to characterize brine migration quantitatively, including the effect of salt expansion and creep, would require an ambitious program of experiment and analysis. Ignoring these mechanisms and ignoring the effect of salt. consolidation can lead to a highly unrealistic and artificial picture of brine migration in a salt repository.

However, quantitative prediction of brine migration may not be needed to predict release rates fron a burfed waste package if the boundary across which release rates are to be calculated is identified as the Inner surface of consolidated salt surrounding the package. Bounding values of the release rates across that surface can be calculated by analysis of solubility-linticed nase-transfer races $[18,19]$.

\section{Effect of Flow In Interbeds Interaecting Dore Holes}

Another source of brine in a salt repository is flow through nonsalt sedinentary layers that ay be present in thin seans surrounded by ealt. here It 1s aseuned that wuch interbede ovcur over horleontal diatances encompasing eny wete packages and that the interbed flow is driven by cone overali preseure sradient. The Interbed brine is likely to be eaturated because of Ite contact with adjacent ealt layers. alchough its composicton wil nt necesearily be the wase that of beine in inclustom and gratn boundarles. It secen valikely that a wate packege wil be knowiagly placed in a bore bole knowa to be incerwected by an laterbod, but if Interbed latereecting

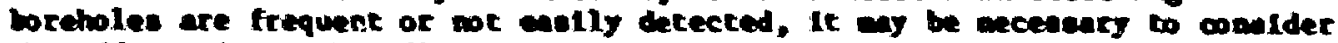

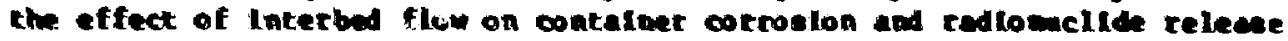
rake. 


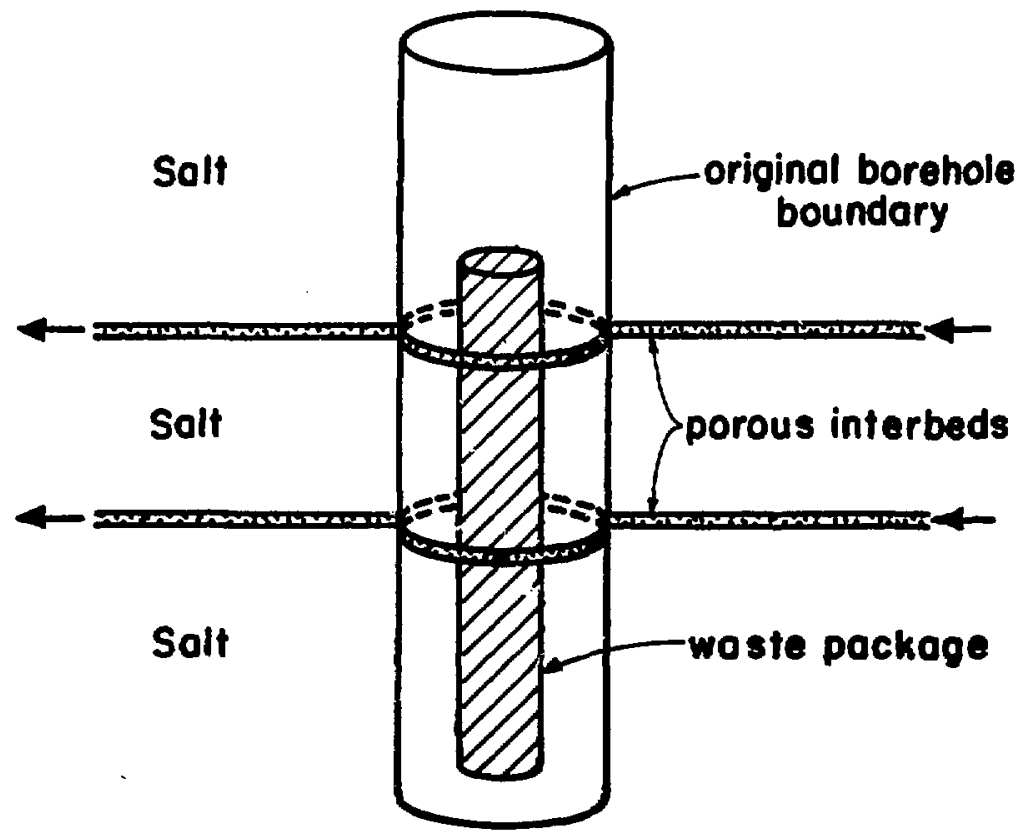

Figure 4. Flow in porous Interbeds Intersesting borehole 
surface of the waste package, as 11lustrated In Flgure 4, we have a pathway for mass transfer of brine water frow the flow through the porous interbed to the waste container surface for chemical reaction and for mass transfer of reaction-generated hydrogen frow the contalner to the interbed brine. Later, assundng that the contalner 18 not present, there is mass transfer of diasolved radionuclides from the cored edge of the interbed into the interbed flow stream. Thls problen of diffusive-convectlve mass transfer for flow in a porous medium surrounding a cyllnder, conservatlvely assuming saturation concentration in the liquid at the cylinder surface, has already been analyzed by Chambre' $[18-20]$.

If the annular bore hole space ls backfilled with salt, creep consolddation should cransform the backfill into a molithic structure connecting the outer salt, and it will -sparate the cored edge of the interbed from the waste package. Interbed brine can diffuse through this conoolidated backfill to corrode the contalner. Later, released radionuclides can diffuse through the consolidated backfill to reach the Interbed water. This is a mass-transfer problem analogous to the problem analyzed by KBS [15-17], whereln groundwater flowing through a horlzontal fracture in grantte supplies sulfide oxidant that diffuses through a compressed bentonite backfill to reach the copper contalner. Later, dissolved radlonuclides, assumed to be at saturation concentrations in liquid at the waste surface, diffuse through the backfill into the noving fracture-flow water. A similar approach is guggested for andyzing the mass transfer from and to interbeds inte-secting the bore holes in a salt repository.

\section{Recounendations}

Main prenises of this discussion are that a brine inclusion renains in grain boundarlea after its therally induced aigration fron the crystal in which it originally resided, that brtne in grain boundaries woves principally under the influence of a pressure gradient, and that the only inportant effect of a monufform temperature profile on intergranular brine 1 so generate chareally a Induced preecure gradient. These may need confirmation by further experisavt. Aleo, the kinetics of salt coneolisation and creep under the influence of lithostatic and tiermally induced stressea should be estiuated. as $\mathrm{mil}$ is the kinetice of preseve-induced flutd wotion near the esitcontatner interface, to escablisir the time pertod at which the wotion of intergranular briae baconea negligible.

The aalyees of tine-depeadent wase transfer descrlbed above should be epplited to enterte the anes-tranefer-linited corrosion rate of the wate contalner and the release rate of redloelement: and radionuclides.

\section{Baferences}

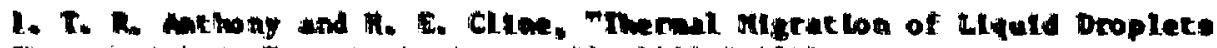

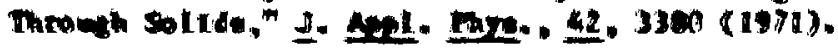


2. G. H. Jenke, "Effects of Teaperature, Temperature Gradients, Streas, and Irradiation on Migration of Brine Inclustons in a Salt Repository," ORNL-5526, JuIy 1979.

3. Ya. B. GeguzIn, A. S. Dzyuba, and V. S. Korzhanov, Sov. Phys. Cryctallogr. 20. 234 (1975).

4. D. R. Olarder, A. J. Machiels, M. Bil, .and S. K. Yagnik, "Thernal Gradient Mgration Inclustons In Syn:het likali Halide Single Crystals," J. Appl. Phys., 53, 669 (1982).

5. T. H. P1gford, "Migration of Brine Inclusions in Salt," Nuclear Technclogy, 56, 93 (1982).

6. T. H. P1gford, "Reply to 'Remarks on Mfgration of Brine Inclusions in Salt", Nuclear Technology, 63, 509 (1983).

7. G. H. Jenks and H. C. Clalborne, "Brine Migration in Salt And Its

Implication in the Geologic Disposal of Nuciear Faste," ORNL-5818, 1981.

8. E. Roedder and H. 己. Beikin, "Migration of Fluld Inclusions 1n

Polycryetalilne Salt Under Thermal Gradients in the Laboratory and in Salt Block II," Iroc. 1980 National Waste Terminel Storage Program Information Mt.g., ONWI-212, p. 361, Office of Nuclear Waste Isolation (1980).

9. D. R. Olander, "A Mbdel of Brine Migration and Water Transport In Rock Salt Supportine a Temperature Gradient," Nuclear Technology, 58, 256 (1982).

10. J. L. Ratigan,, "A Finite element Formulation for Brine Transport In Bock Salt," International Journal for Numerical and Analytical Methode in Geonechanics, 8, 225 (1984).

11. D. F. KicT1gue, "Salt as a Porous Thermolastic Material: Laboratory and Field Applications," SRP Brine Migration Workshop, Berkeley, Ca., Apr11 17-19, 1985.

12. J. A. Lleberman, S. H. Davia, D. R. F. Harlenan, R. L. Reeney, D. Languir, R. B. LYR, W. H. Owens, T. H. PIgford, W. W.-L. Lee, "Performance Asseasment Natlonal Review Croup," Weston Report RFW-CRWH-85-0I, February 1985.

13. J. L. Ratioan, SRP Brine Mgration ibrkshop, Berkeley, Ca., April 17-19, 1985.

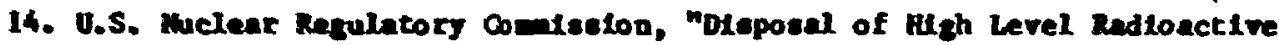
Heste in Cologlc Repositories - Techatcal Cricerla," Title 10. Code of Federal Requlation. Part 60 (1981).

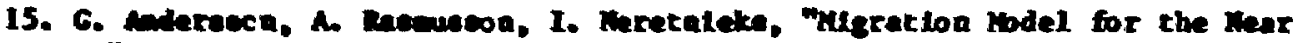

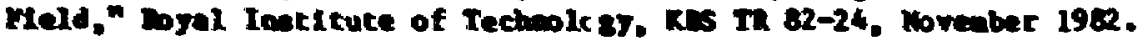


16. I. Neretnieks, "Leach Rates of B1gh Level Waste and Spent Fuel - Liniting Rates as Deternined by Backfill and Bedrock Conditions," Proceedings of the Fifth International Symposiua on the Scientific Basie for Nuclear Waste Management, Berlin, 1982, 559, North-Holland (1982).

17. Swedish Nuclear Fuel Supply Co/Division KBS, "Final Storage of Spent Nuclear Fuel - RBS-3, III Barriers," 1983.

18. Plgford, T. H., J. O. Blomeke, T. L. Brekke, G. A. Cowan, W. E. Falconer, N. J. Grant, J. R. Johnson, J. M. Matusek, R. R. Partzek, R. L. Pigford, D. E. White, "A Study of the Isol.ation System for Geologic Disposal of Radioactive Wastes," National Academy Press, Washington, D.C., April, 1983.

19. P. L. Chambre' and T. H. Plgford, "Prediction of Waste Perfornance in a Geologic Repository," Proceedings of the Materials Research Society, The Scientific Basts for Nuclear Waste Management, Boston, 1983.

20. P. L. Chambre', T. H. Plgford, A. Fujtta, T. Rankf, A. Kobayashi, H. Lung, D. Ting, Y. Sato, 5. J. Zavoshy, "Analytical Performance Wodels for Geologie Repositories," Report LBL-14842, Vo1. II, Chapter 7, October 1982. 